\title{
An Analysis of Music Fan Towards Music Streaming Purchase Intention of Thailand's Music Industry
}

\author{
Pannawit Sanitnarathorn \\ Correspondence: Pannawit Sanitnarathorn, Lecturer, Department of Music Business, Assumption University of \\ Thailand, Thailand.
}

Received: December 2, 2017

doi:10.11114/jets.v6i3a.3161
Accepted: January 24, $2018 \quad$ Online Published: April 1, 2018

URL: https://doi.org/10.11114/jets.v6i3a.3161

\begin{abstract}
Digital music streaming are climbing but overall music revenue is declining with digital music piracy being blamed as the culprit. In a 10 year period from 2003 to 2013, global music sales dropped from \$US23.3 to \$US15 billion dollars with Thailand's music industry following the trend dropping from \$US 304 million in 2010 to \$US 279 million in 2014. The study therefore used a structural equation model to analyze the variables affecting digital music piracy and fan music streaming's purchase intention. From the seven point Likert scale questionnaire, 350 music fans were surveyed concerning their digital music streaming activities. The qualitative research was conducted with 10 executives in music industry by the use of purposive sampling. Partial Least Square Graph software was used for model verification with the results showing that fan idolatry has the highest influence on the overall decision to stream music digitally. The results showed that the results of quantitative research is practical and acceptable hypothesis significance at $p \leq 0.05$ by factors that have a direct influence positive peak and overall influence is the highest passion to affect their willingness to stream music digitally to consumers. The findings of this study concluded that the artist's passion for their music fans is the key factor in music lover's intent to stream and pay for digital music. Fans are ultimately the most important sector of the industry and unfortunately it is one which the industry forgets about. Labels or artists who focus on only 'looking good' while not engaging their fan audiences are destined for a continuing decline in their sales numbers.
\end{abstract}

Keywords: music streaming, idolatry, attitude, subjective norms, purchase intention

\section{Introduction}

Music recording has had a long history of technological evolution which most agree began on December 7, 1877, when Thomas Edison demonstrated his cylinder phonograph at the office of Scientific American in New York City (Edison Paper, 2013). Although technological leaps have been many, one of the first that left a long legacy was the use of 'Vitrolac' which allowed the placing of finer grooves in a record this increasing listening times to 30 minutes. This form of LP recording (long playing) is still used today and was a true milestone in recording history ("New phonograph record", 1932).

Although it was Sony which revolutionized the consumer recording industry with the 'Sony cassette recorder' in 1966 (Nunnally, 1978). it was actually in 1928 when the Dailygraph, the first cassette magnetic recorder was manufactured in Europe (Schoenherr, 2002). It was also Sony which introduced the 'Walkman' in 1979 but it wasn't until 2002 that the new MP3 digital format was introduced to the player via Sony's "Magic Gate Memory Stick" ("Sony's dilemma," 2002).

Apple shortly before had introduced its iconic iPod on October 23, 2001. From that, the technology had made it easier and easier to be a 'music pirate'. During this same period peer to peer (P2P) downloading proliferated with the most infamous of the early companies 'Napster', soaring to 70 million users in its short life between 1999 and 2001, before being shut down by a court's decree (Nieva, 2013). It was Napster that was also the forerunner of today's streaming services such as iTunes Radio and the world's largest streaming music service, Spotify (Ingham, 2016).

Along with the technological developments in music recording, according to Lampel, Bhalla, and Jha (2008), the first generation of intellectual property rights laws for musical creations was born in the period from 1877 to 1890 . It was in this same era that the Berne Convention adopted protection of works and rights of musicians in 1886 as well (WIPO, 2016).

From this period also with the arrival of Edison's gramophone, a niche was created in a music industry dominated by 
publishing and performance. Copyright rules that applied to publishing and performance were transferred to the music industry, and were then adjusted to account for the specific technological nature of its products. Distribution and sales were underdeveloped with many gramophones in the UK sold in bicycle shops.

Time and technology have moved on however, with intellectual property rights of music artist today being all but obliterated due to technological advances (Byun, 2016). The articles and books on this topic are prolific, with most painting a ghostly image of an industry in a death spiral due to the ravenous, unpaid consumption by consumers of digital music which is being distributed in ever increasing, hard to control and regulate, technological ways such as CDs and Napster in the past, and YouTube, Spotify, and iTune streaming over smartphones today (Hirschhorn, 2015; Witt, 2015; Voyce, 2016).

In Thailand however, on the $9^{\text {th }}$ day of December 1994, through a royal decree, the older Copyright Act B.E. 2521 (1978) was repealed and a newer Copyright Act B.E.2537 (1994) was enacted ("Copyright Act B.E. 2537”, 1994) which is actually much newer than the latest amendment to the international Berne Convention which last took place in 1979. In the USA in 1998, the Digital Millennium Copyright Act (DMCS) was passed as well, providing harsher punishments for music fan's file-sharing (DMCA, 1998).

In Thailand the law stipulates that musical copyright if for the entire "life of the author and continues to subsist for fifty years after the death of the author". In chapter 8 of the decree, in an attempt to put 'muscle' behind the law, there is also a long list of penalties, fines and imprisonment times for various violations of the act, depending on if the violation was for personal or commercial use. An example of this is the penalties for infringement of copyright for a commercial purpose in which the offender "shall be inflicted with imprisonment for a term from six months up to four years or a fine from one hundred thousand Baht (\$US2,840) up to eight hundred thousand Baht (\$US22,724) or both imprisonment and fine".

Despite long-standing legal protection in both international courts and national laws, music piracy continues unabated, even after the earlier success with shutting down Napster in 2001 with 52 million users (BBC News, 2001). Shortly thereafter, in the first sentence of the 2002 IFPI Music Piracy Report, it was stated that "Piracy is the greatest threat facing the music industry today," and 14 years later, that has not changed, with piracy now having become the No. 1 threat that obstructs the Thai music sector from growing (PwC, 2015).

Hirschhorn (2015) also discussed the gruesome numbers behind the music industry's inability to control piracy and embrace new business models when reporting on revenue as complied by the Recording Industry Association of America (RIAA) since 1973. In the analysis, income as reported on an inflation-adjusted basis, showed US music sales plummeting 71 percent (\$US 14 billion) since 1999, even though the American population had grown by some 46 million consumers during the same period.

As in the US with 46 million more consumers, a market of consuming music lovers is not the problem in Thailand as well. The problem to the Thai music industry is who consumes it, their perception about its value, and how the music is obtained and paid for, with the data pointing to a youthful, pirating consumer segment often referred to in terms as 'Generation Y' and 'Generation Z'.

In recent years marketers have coined these terms 'Generation $Y$ ' and 'Generation $Z$ ' to describe research about Thai consumer age groups. Simply stated, these are two age groups which represent two separate 'generations' of Thai consumers. The older Generation Y consumers (Thais born between 1981 and 2000) are stated to be some of the most connected users in the world with the Siam Commercial Bank Economic Intelligence Center (2016) indicating that they are the largest consumer component in Thailand. They are also the largest owners of audio and video streaming capable smartphones, with Thailand having over 97 million mobile connections, or 149 percent of the population (eMarketer, 2013; Kemp, 2015). Presently in Thailand over half of the population owns smartphones with the sales of new smartphones in 2016 projected from 15 to 18 million units (Leesa-nguansuk, 2016).

Furthermore, 'Generation Z' is the next generation, which was born after 1995 which globally represents about two billion teenage consumers who are the first generation to be unaware of a world without Internet (Benhamou, 2015). It is this generation that is the main focus of the proposed research.

Digital music streaming has become a new distribution technology that has upended the music industry and triggered a discussion concerning its effects on the bottom line (Datta, Knox, and Bronnenberg, 2016). According to the IFPI (International Federation of the Phonographic Industry) IFPI (2016), global music revenues increase 3.2 percent in 2015 as digital revenues overtook physical sales for the first time ever grabbing 45 percent of the industry reaching US\$ 6.7 billion, with streaming revenues exploding to 45.2 percent to US $\$ 2.9$ billion, remaining the industry's fastest-growing revenue source, growing over the past half-decade more than four-fold. 
Players in this market include Google's YouTube Red and YouTube Music subscription service which goes head-to-head against other services offered by other companies such as Apple Music and Spotify. YouTube initially tried paid content in 2014 with Music Key, with a \$US 7.99 a month, unlimited service, but it never made its way out of beta (Garun, 2015).

Spotify and Deezer are two more of the many music streaming services (Figure 1) that offer consumers access to their database of millions of songs, but it is the creators of Sweden's Spotify that claim their service was designed from the ground up to combat music piracy, and convince people to stop illegal file-sharing, and start consuming music legally again ("Music Streaming vs. Music Piracy," 2014).

The fight for streaming customers however has become a vicious war for market share as can be seen from the length of time that consumers are offered a free trail service in hope of permanently gaining new customers (Figure 1). Additionally, Google's trial crosses multiple services and platforms as well in that it gives customers access to Google Play Music's library of 35 million tracks (\$US 9.99 a month) plus four months of access to YouTube Red which is an ad-free video streaming platform (\$9.99 a month) (Wang, 2016).

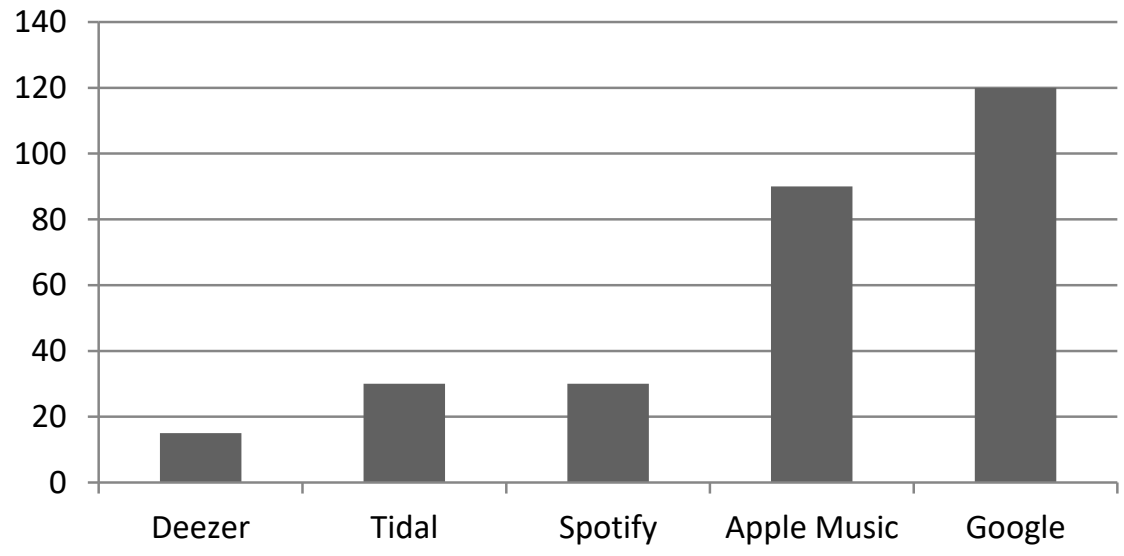

Figure 1. Music steaming platforms free trial periods-Source: Wang (2016)

According to Ingham (2016), Spotify and Apple Music became the leading streaming formats for the first time in music history in the first half of 2016 overtaking on-demand music streams on digital video platforms (e,g, YouTube) which increased just 23 percent in the six months to end of June in the US. Audio music platforms however, where on-demand streams more than doubled, were up 108 percent year-on-year. These increases represented 209.4 billion on-demand US streams of which 114.23 billion streams or 55 percent of the total were from audio streaming platforms only (Figure 2).

\begin{tabular}{c|l|l|l}
\hline & \multicolumn{1}{|c|}{ Video Streams } & \multicolumn{1}{c}{ Audio Streams } & \multicolumn{1}{c}{ Streams } \\
\hline $\mathbf{2 0 1 6}$ & $95,172,077,123$ & $114,226,566,336$ & $209,398,643,459$ \\
$\mathbf{2 0 1 5}$ & 77.297 .473 .064 & $54,961,808,648$ & $132,259,281,712$ \\
\% Change & $23.1 \%$ & $107.8 \%$ & $58.3 \%$ \\
\hline
\end{tabular}

Figure 2. Total on-demand streams in the US market-Source: Ingram (2016)

YouTube Thailand has also seen their numbers soar over a short period, with the newly created channel having risen into the top 10 globally of users watching YouTube videos, doubling the growth rate of most other countries (Bangkok Post, 2015). According to YouTube Thailand, the company in collaboration with local mobile operators will launch a bundled video data plan that allows customers to watch unlimited videos for less than \$US1 a day.

\section{Literature review}

\subsection{Purchase Intention}

Kotler and Armstrong (2001) discussed the dimensions of purchase intention as well as how consumers obtained their information and from what sources and concluded that product information and their sources was crucial as it was done at the beginning of the purchase investigation process which could affect the rest of the consumer's decision making process.

Chiang and Dholakia (2003) also examined online consumer buying and determined that the information acquisition stage consisted of three important variables including convenience, the product's characteristics and product pricing. Kotler (2000) stated that willingness to buy is a measurement of effective consumer behavior. 
Suki, Ramayah, and Suki (2011) studied Malaysian consumers' intention towards software piracy, and determined that there was a significant and positive relationship between subjective norms and attitudes and consumers' intention towards software piracy. This is consistent with Cronan and Al-Rafee (2008) which determined previous music piracy and a consumer's sense of morality affected a person's intention to pirate digital material. Lin, Hsu, Kuo, and Sun (1999) showed that Information Services staff piracy is directly influenced by their opinions, subjective norms, and perceived de-individuation. Buchan (2005) which expanded on research by Ajzen (1985) determined that there was a significant relationship between subjective norms and attitudes with IT staff opinions about ethical issues clearly influencing purchase intention. Additionally, social factors were shown to have a significant influence on attitude formation.

\subsection{Attitude}

In 1937 Murphy, Murphy, and Newcomb (1937) proclaimed that attitude was the most important concept in the entire field of social psychology. Ajzen and Fishbein (1980) later argued that attitudes are comprised of beliefs and evaluations regarding expected outcomes.

Al-Rafee and Cronan (2006) studied digital pirating attitudes and concluded that it is influenced by beliefs about the outcome of behavior, happiness and excitement, age, the perceived importance of the issue, the influence of significant others, and Machiavellianism.

Attitude therefore is considered by many to be a crucial factor in the loss or generation of revenues for the music industry. Attitude has been found to significantly affect an individual's intention to behave ethically or unethically (Fishbein \& Ajzen, 1975; Ajzen \& Fishbein, 1980; Ajzen, 1988, 1991; Olson \& Zanna, 1993). Therefore, understanding the dimensions of attitude will lead to the further understanding of the influences on ethical behavior intention (Leonard $\&$ Cronan, 2005).

\subsection{Idolatry}

A fan is a person who is enthusiastically devoted to something or somebody, such as a band, which is a shortened version of the word fanatic. The word first became popular in reference to baseball enthusiasts deriving from English around 1550 with the word 'fanatic' meaning "marked by excessive enthusiasm and often intense uncritical devotion".

Godin (2008) argued the Internet has ended mass marketing and revived the human social unit called 'tribes'. Founded on shared ideas and values, tribes give ordinary people (fans) the power to lead and make big change. Jenson (1992) also discussed fans and noted two common characterizations of fans; the obsessed individual and the hysterical crowd with fans engage in "artificial relations" with celebrities to compensate for the lack of authentic social relations in the isolated modern day society. Einerson (1998) also indicated that these 'tribal fans' felt remorse about buying pirated goods of artists they idolized. Hyatt (2014) went on to discuss the hierarchy of fandom which was listed as superfans, engaged fans and ambient fans.

\subsection{Subjective Norms}

According to two leading theories of attitude-behaviour relations, the theory of reasoned action (TRA) and the theory of planned behaviour (TPB), subjective norms and attitude are independent variables with a significant causal relationship to intention (Ajzen \& Fishbein, 1975). Ajzen (1991) in a review of the theory of planned behavior restated that intentions to perform behaviors of different kinds can be predicted with high accuracy from attitudes toward the behavior, subjective norms, and perceived behavioral control. Liao, Liu, Lu and To (2008) confirmed that attitude and subjective norms had a very significant influence on consumers' intention of purchasing digital products. This is consistent with additional studies by Chang (1998), Shepherd and O'Keefe (1984), and Al-Rafee and Cronan (2006) which also found that subjective norms influence attitudes to purchase digital music.

\subsection{Perceived Behavioural Control}

According to Terry and O'Leary (1995) two variables comprise the notion of perceived behavioural control (PBC) which include behavior control and efficacy expectancies. Trafimow, Sheeran, Conner, and Finlay's (2002) results from four studies on Ajzen's $(1988,1991)$ concept of PBC determined that it is an amalgamation of two variables termed 'perceived control' and 'perceived difficulty'. Lin (2013) discussed what was termed as 'free mentality' which is a strong belief that everything online should be free which has significantly affected the development of e-commerce. This is consistent with Yoon (2011) which stated that digital piracy has posed a significant threat to the development of the software industry and the growth of the digital media industry.

From the above conceptual review and development, the researchers developed the following six hypotheses:

H1: Idolatry directly affects Purchase Intention

H2: Idolatry directly affects Attitude 
H3: Subjective Norms directly affects Purchase Intention

H4: Subjective Norms directly affects Attitude

H5: Attitude directly affects Purchase Intention

H6: Perceived Behavioural Control directly affects Purchase Intention

\section{Methodology}

This research developed a structural equation model of the antecedents affecting Thai 'Y-Generation' consumers' willingness to download and purchase digital music in digital form. Y-Generation or millennials are individuals born between 1980 and 1995 .

\subsection{Data Collection}

For quantitative research a questionnaire was developed. The study determined the sample size of the age group to be 16-34 years old 'Y-Generation' Thais who experience listening to online, digital music.

According to Bacon (2001), published Structural Equation Model (SEM) applications normally use 200-400 participants to fit models with 10-15 observed variables. This is consistent with Yamane (1967) and Israel (1992) that indicates that sample sizes beyond 400 is almost useless. According to Lindeman, Merenda and Gold (1980) sampling size should be determined by 20:1 ratio between the total and observed variables. Based on these scholars research, from the 5 latent variables in the model, 9 observed variables were analyzed from which 180 samples were deemed sufficient. The study however nearly doubled the sample number to 350 which is deemed as highly reliable. Alpha coefficient was used to determine internal consistency which ranges in value from 0 to 1 and may be used to describe the reliability of factors extracted from the study's 7 point Likert (1932) scale formatted questionnaire. The resultant alpha coefficients ranged from 0.532 to 0.945 (highly reliable).

\subsection{Variables}

\subsubsection{Dependent Variables Measurement}

Purchase Intention included the observed variables likelihood of purchase (LEP) and recommendation (ROC) which had loading values of 0.926 and 0.874 respectively with a significant level of confidence at 95 percent $(|t| \geq 1.96)$ as shown in Table 1.

Attitude included the observed variables cognitive (COG) and behavioral (REH) which had loading values of 0.934 and 0.854 respectively with a significant level of confidence at 95 percent $(|t| \geq 1.96)$ as shown in Table 1 .

\subsubsection{Independent Variables Measurement}

Idolatry included identification (IDE) and worshiping (WOR) which had loading values of 097.6 and 0.976 respectively, with a significant level of confidence at 95 percent $(|t| \geq 1.96)$ as shown in Table 1.

Subjective Norms included the observed variables social pressure (SPP) and normative belief (SEB) which had loading values of 0.953 and 0.921 respectively, with a significant level of confidence at 95 percent $(|t| \geq 1.96)$ as shown in Table 1.

Perceived Behavioural Control included the observed variable self-efficacy (SFF) which had a loading value of 1.000 , with a significant level of confidence at 95 percent $(|t| \geq 1.96)$ as shown in Table 1.

\subsection{Data Analysis}

Henseler et al. (2014) indicated that PLS is an important statistical tool for research. PLS-Graph software was used to discover the causal relationships of the structural equation model (SEM) as presented in Figure 2 (Piriyakul, 2011). This involved defining the observed or manifest variables with the latent variables, which were then analyzed for their accuracy and reliability of the measurement.

Measurement results showed that the mean correlation was reliable ranging from 0.532 to 0.945 . All values had statistical significance (Table 1) by ( $|t| \geq 1.96)$ (Lauro and Vinzi, 2004; Henseler et al., 2009). 
Table 1. Statistic values presenting convergent validity of reflective scales of latent variables

\begin{tabular}{lcc}
\hline Construct/Item & Loading & t-stat \\
\hline Idolatry & & \\
$\quad$ IDE: identification & 0.976 & 144.784 \\
$\quad$ WOR: worshiping & 0.976 & 101.571 \\
\hline Attitude & & \\
$\quad$ COG: cognitive & 0.808 & 22.818 \\
$\quad$ BEH: behavioral & 0.846 & 27.905 \\
\hline Subjective Norms & & \\
$\quad$ SPP: social pressure & 0.921 & 57.780 \\
$\quad$ SEB: normative belief & 0.942 & 74.890 \\
\hline Perceived Behavioural Control & & \\
$\quad$ SFF: self-efficacy & 0.926 & 46.125 \\
\hline Purchase Intention & & \\
$\quad$ LOP: likelihood of purchase & 0.879 & 56.875 \\
$\quad$ REC: recommendation & 0.927 & 151.484 \\
\hline
\end{tabular}

In Table 2, discriminant validity and the scale reliability were analyzed from Composite Reliability (CR) as well as the Average Variance Extracted (AVE). The CR value should be maintained above 0.60 while the AVE values be lower than 0.50. Additionally, the coefficient of determination (R2) value should always exceed 0.20 (Lauro and Vinzi, 2004; Henseler and Fassott, 2010).

Table 2. Statistical discriminant validity

\begin{tabular}{|c|c|c|c|c|c|c|c|c|}
\hline \multirow[b]{2}{*}{ Construct } & \multirow[b]{2}{*}{ CR } & \multirow[b]{2}{*}{$\mathbf{R}^{2}$} & \multirow[b]{2}{*}{ AVE } & \multicolumn{5}{|c|}{ correlation } \\
\hline & & & & Idolatry & Attitude & $\begin{array}{l}\text { Perceived } \\
\text { Behavioral } \\
\text { Control }\end{array}$ & $\begin{array}{c}\text { Subjective } \\
\text { Norms }\end{array}$ & $\begin{array}{l}\text { Purchase } \\
\text { Intention }\end{array}$ \\
\hline Idolatry & 0.786 & & 0.630 & 0.793 & & & & \\
\hline Attitude & 0.801 & & 0.578 & 0.167 & 0.760 & & & \\
\hline $\begin{array}{l}\text { Perceived } \\
\text { Behavioral } \\
\text { Control }\end{array}$ & 0.857 & & 0.751 & 0.378 & 0.521 & 0.866 & & \\
\hline $\begin{array}{l}\text { Subjective } \\
\text { Norms }\end{array}$ & 0.774 & & 0.590 & 0.032 & 0.287 & 0.064 & 0.768 & \\
\hline $\begin{array}{l}\text { Purchase } \\
\text { Intention }\end{array}$ & 0.895 & & 0.810 & 0.776 & 0.210 & 0.328 & 0.128 & 0.875 \\
\hline
\end{tabular}

Note: The boldface numbers on the diagonal are the square root of the variance $\sqrt{A V E}$. Statistical significance level is at 0.01 and diagonal figures mean.

The analysis of the influence of idolatry, Subjective Norms, Attitude and Perceived Behavioural Control on Thai consumer Purchase Intention of digital music (Figure 3). 


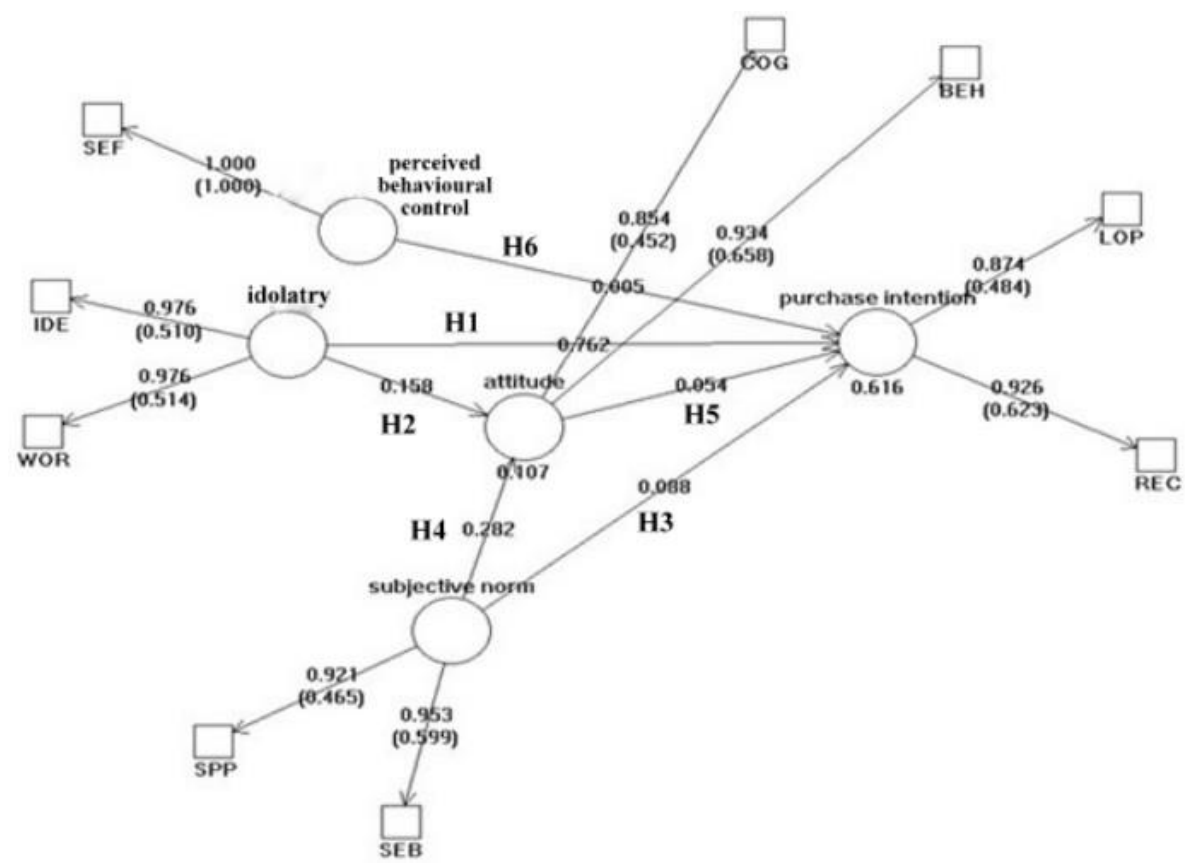

Figure 3. Final Model

\section{Results and Discussion}

Since the 1970s, the theory of reasoned action (TRA) (Ajzen \& Fishbein, 1980; Fishbein \& Ajzen, 1975) and its extension, the theory of planned behaviour (TPB) (Ajzen, 1991) have been regarded as the leading theories of the attitude-behaviour relationship. From the syntheses of these theories and other studies, it was determined that the following factors play important roles in Thai Generation Y's digital music purchase intention (Amornvivat, 2014).

Idolatry refers to psychological identification and an emotional attachment to an idol figure, which is probably a celebrity (Cheung \& Yue, 2012) whose attachment is greatest with younger children, decreasing in intensity with age with females idolizing singers more than males (Raviv, Bar-Tal, Raviv, \& Ben-Horin, 1996). Wang, Chen, Yang, and Farn (2009) also indicated that as fan idolatry increases, the willingness to commit digital piracy decreases and the willingness to purchase increases. Chiou et al. (2005) stated music piracy is the greatest threat facing the music industry worldwide today but if fans have passion for the artist or band, fans will be less willing to illegally download or pirate their music.

Subjective Norms consists of two empirical observations or variables including normative belief (an individual's perception of social normative pressures) and social pressure. They are an individual's perception about the particular behavior, which is influenced by the judgment of others such as parents, parents, spouses, friends, and teachers.

Attitude concerning digital piracy was studied by Al-Rafee and Cronan (2006) and concluded that it is influenced by beliefs about the outcome of behavior (cognitive beliefs), happiness and excitement (affective beliefs), age, the perceived importance of the issue, the influence of significant others (subjective norms), and Machiavellianism.

Perceived behavioral control consisted of an empirical observation or variable termed self-efficacy. Logically, perceived behavioral control, rather than having a direct effect, is expected to interact with attitudes and with subjective norms in determining intentions, and with intentions in its effects on behavior (Ajzen, 1985).

Purchase Intention as discussed by Huang, Lin, Su, and Tung (2015) suggested that both social worship and personal worship have a significant and positive impact on the intention to purchase music but personal worship has a negative impact on the intention to pirate music while social worship appears to strengthen it.

\section{Conclusion}

The findings of this study concluded that the artist's passion for their music fans is the key factor in music lover's intent to download and pay for digital music. Fans are ultimately the most important sector of the industry and unfortunately it is one which the industry forgets about. Labels or artists who focus on only 'looking good' while not engaging their fan audiences are destined for a continuing decline in their sales numbers. Entrepreneurs and music industry leaders need to be aware of and engage the 'hierarchy of fandom' which is stated to have 1) superfans, 2) engaged fans, and 3) ambient fans (Hyatt, 2014) and come to understand the marketing concept of 'Direct to Fan (D2F)'. It is clear from the 
research that when artists engage their audience and fans, idolatry increases and thus the less likelihood of digital music piracy. Devotion increases sales at all levels, from concert tickets, to souvenirs to music tracks. Music industry entrepreneurs need to produce musical events for their consumers but not 'oversell' the related merchandise. The above ideas can best be summarized from the global TV performance on June, 251967 in which the Beatle's sang, 'All you need is love' which was watched live by over 400 million people in 25 countries (Davies, 1996).

\section{References}

Ajzen, I. (1985). From intentions to actions: A theory of planned behavior. In J. Kuhi and J. Beckmann (Eds.), Action control: From cognition to behavior (pp. 11-39). Heidelberg: Springer. https://doi.org/10.1007/978-3-642-69746-3_2

Ajzen, I. (1988). Attitudes, Personality, and Behavior. Berkshire, UK: Open University Press.

Ajzen, I. (1991). The Theory of Planned Behavior. Organizational Behavior and Human Decision Processes,50, 179-211. https://doi.org/10.1016/0749-5978(91)90020-T

Ajzen, I., \& Fishbein, M. (1980). Understanding attitudes and predicting social behavior. Englewood Cliffs, NJ: Prentice-Hall.

Al-Rafee, S., \& Cronan, T. (2006). Digital Piracy: Factors that Influence Attitude toward Behavior. Journal of Business Ethics, 63(3), 237-259. https://doi.org/10.1007/s10551-005-1902-9

Amornvivat, S. (2014, November 19). Connecting with Thai 'Gen Y' consumers, Bangkok Post. Retrieved from http://tinyurl.com/qgqdcop

Bacon, L. D. (2001). Using Amos for structural equation modeling in market research. Lynd Bacon \& Associates Ltd. and SPSS Inc. Retrieved from http://tinyurl.com/hmd8qyc

Bangkok Post. (2015). YouTube sees record gain (2015, May 26). Retrieved from http://tinyurl.com/zqsah97

BBC News. (2001). Court blow to Napster. 2001, February 12. BBC News. Retrieved from http://tinyurl.com/hg7gnnd

Benhamou, L. (2015, February 11). Generation Z: Born in the digital age. The Nation. Retrieved from http://tinyurl.com/zqlos4q

Buchan, H. F. (2005). Ethical Decision Making in the Public Accounting Profession: An Extension of Ajzen's Theory of Planned Behavior. Journal of Business Ethics, 61(2), 165-181. https://doi.org/10.1007/s10551-005-0277-2

Byun, C. (2016). The economics of the popular music industry: Modelling from microeconomic theory and industrial organization. Springer Publishing. https://doi.org/10.1057/9781137467058

Chang, M., (1998). Predicting Unethical Behavior: A Comparison of the Theory of Reasoned Action and the Theory of Planned Behavior. Journal of Business Ethics, 17, 1825-1834. https://doi.org/10.1007/978-94-007-4126-3_21

Cheung, C. K., \& Yue, X. D. (2012). Idol worship as compensation for parental absence. International Journal of Adolescence and Youth, 17(1), 35-46. https://doi.org/10.1080/02673843.2011.649399

Chiang, K. P., \& Dholakia, R. R. (2003). Factors driving consumer intention to shop online: An empirical investigation. Journal of Consumer Psychology, 13, 177-183. https://doi.org/10.1207/153276603768344898

Chiou, J. S., Huang, C. Y., \& Lee, H. H. (2005). The Antecedents of Music Piracy Attitudes and Intentions. Journal of Business Ethics, 57(2), 161-174. https://doi.org/10.1007/s10551-004-5263-6

Copyright Act B. E. 2537 (1994). Retrieved from http://tinyurl.com/zj6wojt

Cronan, T. P., \& Al-Rafee, S. (2008). Factors That Influence the Intention to Pirate Software and Media. Journal of Business Ethics, 78(4), 527-545. https://doi.org/10.1007/s10551-007-9366-8

Datta, H., Knox, G., \& Bronnenberg, B. J. (2016). Changing their tune: How consumers' adoption of online streaming affects music consumption and discovery. Retrieved from http://tinyurl.com/hxmvk41

Davies, H. (1996). The Beatles, New York: Norton and Co.

DMCA (1998). Digital Millennium Copyright Act. Retrieved from http://tinyurl.com/6u7hf

Edison Papers (2013). Retrieved from http://tinyurl.com/7go6wj2

Einerson, M. J. (1998). Fame, Fortune, and Failure: Young Girls' Moral Language Surrounding Popular Culture. Youth \& Society, 30(2), 241-257. https://doi.org/10.1177/0044118X98030002005

eMarketer (2013, January 15). 'Generation Y' leads the way on smartphones. Retrieved from http://tinyurl.com/jad7rgp

Fishbein, M., \& Ajzen, I. (1975). Belief, Attitude, Intention, and Behavior, Reading, MA: Addison-Wesley. 
Garun, N. (2015). YouTube Red takes on Netflix with a subscription service for ad-free original content. Retrieved from http://tinyurl.com/zdblnys

Godin, S. (2008). Tribes: We Need You to Lead Us, Portfolio Press.

Henseler, J., \& Sarstedt, M. (2013). Goodness-of-fit indices for partial least squares path modeling. Computer Statistics, 28, 565-580. https://doi.org/10.1007/s00180-012-0317-1

Hirschhorn, J. (2015, July 26). Less Money, Mo' Music \& Lots of Problems: A Look at the Music Biz. Retrieved from https://doi.org/10.1108/APJML-03-2014-0050

Huang, Y. A., Lin, C., Su, H. J., \& Tung, M. L. (2015). I worship, so I download? Idol worship, music purchase and piracy by young consumers in Taiwan. Asia Pacific Journal of Marketing and Logistics, 27(1), 99-126. https://doi.org/10.1108/APJML-03-2014-0050

Hyatt, A. (2014). The A to Z of Direct To Fan (D2F). Retrieved from http://tinyurl.com/zfwft53

IFPI (2016, April 12). Global Music Report 2016. Retrieved from http://tinyurl.com/gwpzbys

Ingham, T. (2016). YouTube's dominance takes a beating from Spotify, Apple Music and co. Retrieved from http://tinyurl.com/z5af6q3

Israel, G. D. (1992). Determining Sample Size. Fact Sheet PEOD-6. Retrieved from http://tinyurl.com/gvun8cb

Jenson, J. (1992). Fandom as Pathology: The Consequences of Characterization. In L. A. Lewis (Ed.), The Adoring Audience: Fan Culture and Popular Media, (pp. 9-29), London: Routledge.

Kemp, S. (2015). Digital, social \& mobile in Southeast Asia in 2015. We are social. Retrieved from http://tinyurl.com/h5quwba

Kotler, P., \& Amstrong, G. (2001). Principles of Marketing (5 ${ }^{\text {th }}$ ed.). Upper Saddle River: New Jersey: Prentice Hall.

Lampel, J., Bhalla, A., \& Jha, P. (2008). Intellectual property rights and industry evolution: The case of the recorded music industry. Retrieved from http://tinyurl.com/j5sy26m

Lauro, C., \& Vinzi, V. E. (2004). Some contributions of PLS path modeling and a system for

Leesa-nguansuk, S. (2016). Flat smartphone growth as market reaches saturation. Bangkok Post. Retrieved from http://tinyurl.com/zm427ak

Leonard, L. N. K., \& Cronan, T. P. (2005). Attitude toward ethical behavior in computer use: a shifting model. Industrial Management \& Data Systems, 105(9), 1150-1171. https://doi.org/10.1108/02635570510633239

Liao, C., Liu, C. C., Lu, Y., \& To, P. L. (2008). Physical or Digital? Factors Drive Consumers to Purchase Digital Music. Conference: Pacific Asia Conference on Information Systems, PACIS 2008. Retrieved from http://tinyurl.com/jbwkjnp

Likert, R. (1932). A technique for the measurement of attitudes. Archives of Psychology, 22, 140. Retrieved from http://tinyurl.com/z5f2nmx

Lin, T. C. (2013). Customer willingness to pay for online music: The role of free mentality. Journal of Electronic Commerce Research, 14(4). Retrieved from http://tinyurl.com/jhwphzd

Lin, T. C., Hsu, M. H., Kuo, F. Y., \& Sun, P. C. (1999). An Intention Model-based Study of Software Piracy. Proceedings of the 32nd Hawaii International Conference on System Sciences. Retrieved from http://tinyurl.com/hagotkp

Lindeman, R. H., Merenda, P. F., \& Gold, R. Z. (1980). Introduction to Bivariate and Multivariate Analysis. Glenview, IL: Scott, Foresman.

Murphy, G., Murphy, L., \& Newcomb, T. (1937). Experimental Social Psychology. New York: Harper and Row.

Music Streaming vs. Music Piracy (2014). Retrieved from http://tinyurl.com/jfxyoox

New phonograph record plays half hour music program (1932, February). Retrieved from http://tinyurl.com/jumach5

Nieva, R. (2013, September 5). Ashes to ashes, peer to peer: An oral history of Napster. Fortune. Retrieved from http://tinyurl.com/gv4ncuv

Nunnally, J. C. (1978). Psychometric Theory (2nd ed.). New York, USA: McGraw Hill. Promoting Compact Cassettes Worldwide (2016). Sony Corporate history: Chapter 5. Retrieved from http://tinyurl.com/z2bjugj

Olson, J., \& Zanna, M. (1993). Attitudes and Attitudes Change. Annual Review of Psychology, 44, 117-154. https://doi.org/10.1146/annurev.ps.44.020193.001001 
PwC. (2015). Digital platforms lift Thai media \& entertainment spending (2015). PwC. Retrieved from http://tinyurl.com/gmpx7fo

Raviv, A., Bar-Tal, D., Raviv, A., \& Ben-Horin, A. (1996). Adolescent Idolization of Pop Singers: Causes, Expressions and Reliance. Journal of Youth and Adolescence, 25(5), 631-650. https://doi.org/10.1007/BF01537358

Schoenherr, S. (2002). The history of magnetic recording. Retrieved from http://tinyurl.com/za4n7uy

Shepherd, G., \& O'Keefe, D. (1984). Separability of Attitudinal and Normative Influences on Behavioral Intentions in the Fishbein-Ajzen Model. The Journal of Social Psychology, 122, 287-288. https://doi.org/10.1080/00224545.1984.9713496

Siam Commercial Bank Economic Intelligence Center (2016, March 9). Unveiling 4G business models in the digital world. Retrieved from http://tinyurl.com/hy5mbet

Sony's dilemma: Illegally copied music on Walkman (2002, January 2). CNET. Retrieved from http://tinyurl.com/hrzdfdc

Suki, N. M., Ramayah, T., \& Suki, N. M. (2011). Understanding Consumer Intention with Respect to Purchase and Use of Pirated Software. Information Management and Computer Security, 19(3), 195-210. https://doi.org/10.1108/09685221111153564

Terry, D. J., \& O'Leary, J. E. (1995). The theory of planned behaviour: The effects of perceived behavioural control and self-efficacy. British Journal of Social Psychology, 34, 199-220. https://doi.org/10.1111/j.2044-8309.1995.tb01058.x

The European customer satisfaction, Dipartimento di Matematica e Statistica, Universita Federico II di Napoli, pp. 201-210 Retrieved from http://tinyurl.com/hdc2anx

Trafimow, D., Sheeran, P., Conner, M., \& Finlay, K. A. (2002). Evidence that perceived behavioural control is a multidimensional construct: Perceived control and perceived difficulty. British Journal of Social Psychology, 41, 101-121. https://doi.org/10.1348/014466602165081

Voyce, M. (2016, June 30). The day Napster died and changed the music industry forever. Nerdist. Retrieved from http://tinyurl.com/h7krr7a

Wang, A. (2016, July 5). Google joins Apple Music in giving a whole lot of music away for free. Retrieved from http://tinyurl.com/hgf9kzk

Wang, C., Chen, C., Yang, S., \& Farn, C. (2009). Pirate or Buy? The Moderating Effect of Idolatry. Journal of Business Ethics, 90(1), 81-93. https://doi.org/10.1007/s10551-009-0027-y

WIPO (2016). Berne Convention for the Protection of Literary and Artistic Works. World Intellectual Property Organization. Retrieved from http://tinyurl.com/yapqrkx

Witt, S. (2016, April 27). The man who broke the music business: The dawn of online piracy. The New Yorker. Retrieved from http://tinyurl.com/ooy9h6t

Yamane, T. (1967). Statistics, An Introductory Analysis (2nd Ed.). New York: Harper and Row.

Yoon, C. (2011). Theory of Planned Behavior and Ethics Theory in Digital Piracy: An Integrated Model. Journal of Business Ethics, 100(3), 405-417 https://doi.org/10.1007/s10551-010-0687-7

\section{Copyrights}

Copyright for this article is retained by the author(s), with first publication rights granted to the journal.

This is an open-access article distributed under the terms and conditions of the Creative Commons Attribution license which permits unrestricted use, distribution, and reproduction in any medium, provided the original work is properly cited. 